\title{
Perbandingan Efektivitas Daya Hambat Antibakteri Ekstrak Rimpang Jahe Merah (Zingiber officinale var rubrum) dengan Formula Obat Kumur Lidah Buaya Terhadap Pertumbuhan Bakteri Staphylococcus aureus
}

Nadia Amatul Khayum ${ }^{1}$, Rima Semiarti², Nelvi Yohana ${ }^{1}$

Korespondensi :Nelvi Yohana; nelvi yohana@yahoo.com Telp: +6281375136616

\begin{abstract}
Red Ginger extract and Aloe vera mouthwash formulae have an antibacterial properties. The Red Ginger extract contains of gingerol, essential oil, terpenoid, fenol, flavonoid, and the Aloe vera mouthwash formulae contains of aloe berbadensis. This compound can be used in inhibition against the growth of Staphylococcus aureus that cause infections. The method of this research is a laboratory experimental. The Red Ginger extract prepared by maceration method with $96 \%$ ethanol solvent. The Aloe vera mouthwash formulae is the ready stock. Discs soaked into two groups solution for 15 minutes, then placed on MHA media contain Staphylococcus aureus to see the inhibition power. The result showed that the Red Ginger extract and Aloe vera mouthwash formulae show the inhibiting power with a strong category. The average diameter inhibiting power of Red Ginger extract is 10,75 $\mathrm{mm}$ and Aloe vera mouthwash formulae is 12,82 mm. Independent Sample T-test showed the significance value is $0,00(p<0,05)$. The conclusion of this reasearch is that the Aloe vera mouthwash formulae is more effective than Red Ginger extract in inhibiting the growth of Staphylococcus aureus.
\end{abstract}

Keywords: red ginger extract, aloe vera mouthwash formulae, antibacterial, inhibition zone's diameter, staphylococcus aureus

Affiliasi penulis: ${ }^{1}$ Faculty of Dentistry, Universitas Andalas, Padang, Indonesia; ${ }^{2}$ Faculty of Medicine, Universitas Andalas, Padang, Indonesia

PENDAHULUAN

Masyarakat Indonesia mengenal dan memakai tanaman berkhasiat obat yang menjadi salah satu upaya dalam penanggulangan masalah kesehatan yang dihadapi.Kemajuan teknologi dan ilmu pengetahuan modern yang semakin pesat dan canggih di zaman sekarang ini, ternyata tidak mampu menggeser atau mengesampingkan begitu saja obat tradisional.Hal ini terbukti dari banyaknya peminat pengobatan tradisional. ${ }^{1}$ Namun yang menjadi masalah dan kesulitan bagi para peminat obat tradisional adalah kurangnya pengetahuan dan informasi mengenai berbagai jenis tumbuhan yang dipakai sebagai obat tradisional untuk pengobatan penyakit tertentu dan cara pemanfaatannya. Jenis tumbuhan yang berkhasiat obat diantaranya adalah jahe merah (Zingiber officinale var rubrum) dan lidah buaya (Aloe vera).

Tanaman jahe (Zingiber officinale) sudah lama dikenal dan dipergunakan oleh masyarakat sebagai tanaman obat. Jahe (Zingiber officinale) adalah salah satu tanaman yang digunakan sebagai 
bahan mentah dalam pembuatan obat modern maupun obat-obatan tradisional.Beberapa penelitian menunjukkan bahwa ekstrak jahe (Zingiber officinale) mempunyai efek antibakteri terhadap bakteri Gram positif dan Gram negatif. Berdasarkan bentuk, warna, dan ukuran rimpang, ada 3 jenis jahe (Zingiber officinale) yang dikenal, yaitu jahe putih besar atau jahe badak, jahe putih kecil atau jahe emprit dan jahe sunti atau jahe merah. ${ }^{2}$

Jahe merah (Zingiber officinale var. rubrum) merupakan tanaman yang telah banyak diteliti dan memiliki aktivitas antibakteri. Kandungan senyawa yang terdapat pada jahe merah (Zingiber officinale var. rubrum) yang dapat memberikan aktivitas antibakteri diantaranya flavonoid, fenol, glikosida, minyak atsiri, triterpenoid, dan tannin. Ekstrak rimpang jahe merah (Zingiber officinale var. rubrum) memiliki efek antibakteri terhadap bakteri Gram positif dan bakteri Gram negatif. ${ }^{3}$ Ada beberapa bakteri gram positif seperti Staphylococcusaureus, Staphylococcus epidermidis, Staphylococcus agalactiae,Listeria monocytogenes dan Propionibacterium acnes yang dapat dihambat oleh ekstrak jahe merah (Zingiber officinale var. rubrum). ${ }^{4}$ Minyak atsiri pada jahe merah (Zingiber officinale var. rubrum) terbukti mampu menghambat pertumbuhan bakteri Gram-positif dan bakteri Gram-negatif. ${ }^{5}$

Suatu penelitian menunjukkan bahwa ekstrak jahe merah (Zingiber officinale var. rubrum) dengan konsentrasi 100\% efektif dalam membunuh Candida albicans pada akrilik dalam waktu 6 jam. ${ }^{6}$ Kandungan senyawa fenol pada jahe (Zingiber officinale) memiliki kemampuan untuk menghambat pertumbuhan bakteri E.coli dan ekstrak jahe merah (Zingiber officinale var. rubrum) dalam konsentrai $50 \%$ efektif membunuh bakteri Streptococcus mutans pada plat resin akrilik heat cured. ${ }^{7}$ Ekstrak rimpang jahe merah (Zingiber officinale var. rubrum) dapat menghambat pertumbuhan bakteri Streptococcus mutans pada konsentrasi 3,125\%,6,25\%, 12,5\%, 25\% dan 50\%. Pada hasil penelitian Prasetya (2012), menyatakan bahwa ekstrak jahe (Zingiber officinale) pada konsentrasi $80 \%$ lebih efektif dalam meghambat pertumbuhan bakteri Streptococcus mutans bila dibandingkan dengan konsentrasi $20 \%, 40 \%$, dan 60\%. ${ }^{8}$

Lidah buaya (Aloe vera) merupakan tanaman yang sudah banyak digunakan sebagai pengobatan di rumah dan pengobatan Cina dan Arab. ${ }^{1}$ Menurut beberapa pakar kesehatan, lidah buaya (Aloe vera) tercantum dalam daftar tanaman obat prioritas WHO dan telah dimanfaatkan dalam bidang kedokteran di 23 negara serta mulai dikembangkan untuk meningkatkan ekonomi masyarakat bawah. ${ }^{9}$

Menurut Ganitafuri (2010), lidah buaya mengandung komponen aktif yang meliputi anthraquinon, aloesin, aloin, aloe-emodin, acemannan, saponin, sterol, asam amino, mineral, enzim dan komponen lain yang sangat bermanfaat bagi kesehatan. ${ }^{1}$ Aktivitas antibakteri lidah buaya (Aloe vera) mampu menghambat pertumbuhan bakteri, baik bakteri Gram positif maupun Gram negatif dan lidah buaya (Aloe vera) memiliki daya antimikroba pada beberapa bakteri yaitu Staphylococus aureus, Pseudomonas aeroginosa, Candidaalbicans,Klebsiella pneumonia, Enterococcus faecalis, danMicrococcus luteus. Tanamanlidah buaya (Aloe vera) ini juga memiliki berbagai potensi sebagai antiinflamasi, antibakteri, antioksidan, antiviral, antijamur, dan juga membantu proses regenerasi sel. ${ }^{10}$

Pada penelitian Hayati (2009), menunjukkan bahwa lidah buaya (Aloe vera) dapat merangsang pertumbuhan fibroblas untuk meningkatkan penyembuhan luka, menghalangi penyebaran dan membunuh bakteri penyebab infeksi. Penelitian secara in vitro mengatakan bahwa lidah buaya (Aloe vera) dengan 
konsentrasi $1,562 \%$ memiliki daya hambat terhadap bakteri Streptococcusmutans, dan semakin tinggi konsentrasi maka daya hambat lidah buaya (Aloe vera) akan semakin tinggi pula. ${ }^{9}$

Sediaan lidah buaya (Aloe vera) yang diolah dalam bentuk obat kumur dapat membantu dalam penatalaksanaan nyeri pada rongga mulut seperti, stomatitis aftosa, lesi kecil, termasuk lesi traumatik yang disebabkan oleh kawat gigi dan gigi tiruan yang tidak sesuai. ${ }^{9}$ Obat kumur merupakan larutan atau cairan yang digunakan untuk membilas rongga mulut dengan tujuan untuk menyingkirkan bakteri pathogen, bekerja sebagai anti inflamasi, untuk menghilangkan bau tidak sedap dan menghilangkan infeksi. Penggunaan obat kumur oleh masyarakat semakin meningkat karena kesadaran masyarakat akan pentingnya kesehatan gigi dan mulut. ${ }^{11}$ Pemakaian obat kumur dapat menimbulkan efek samping, tetapi hanya bersifat temporer dan tidak membahayakan. Jika pemakaian dihentikan efeknya akan berangsur angsur menghilang. ${ }^{12}$

Bakteri Staphylococcus aureus merupakan flora normal dalam rongga mulut yang dapat berubah menjadi patogen bila terjadi trauma atau abrasi pada permukaan mukosa.Bakteri ini dapat menyebabkan sebagian infeksi pada daerah rongga mulut dan menyebabkan penyakit melalui invasi ke jaringan dan pengeluaran toksin. ${ }^{13}$ Bakteri Staphylococcus aureus ini mempunyai peranan penting dalam menyebabkan maupun memperparah banyak penyakit pada rongga mulut dan dapat menyebabkan abses, gingivitis dan denture stomatitis. ${ }^{9}$

Bakteri Staphylococcus aureus iniditemukan mempunyai prevalensi tinggi pada pasien denture stomatitis. Menurut Hayati (2009) prevalensi Candida albicans, Staphylococcus aureus, dan Streptococcus mutans pada pasien denture stomatitis adalah $51,4 \%, 52,4 \%$, dan $67,6 \% .{ }^{9}$ Bakteri ini juga menyebabkan abses pada rongga mulut yang ditandai oleh adanya lubang yang berisi nanah (pus) dalam jaringan dan bakteri ini memiliki frekuensi yang meningkat dari $0,7 \%$ menjadi $15 \%$ pada kasus dental abses. ${ }^{14}$

Berdasarkan uraian di atas, terdapat keterkaitan antara aktivitas antibakteri rimpang jahe merah (Zingiber officinale var rubrum) dengan formula obat kumur lidah buaya yang banyak digunakan dalam bidang kedokteran dan kehidupan sehari - hari.Maka, penulis tertarik untuk melakukan penelitian tersebut tentang perbandingan efektivitas daya hambat antibakteri ekstrak rimpang jahe merah (Zingiber officinale var rubrum) dengan formula obat kumur lidah buaya terhadap pertumbuhan bakteri Staphylococcus aureus.

\section{METODE}

Jenis penelitian yang dilakukan adalah eksperimental laboratorium. Besar sampel dalam penelitian ini dihitung menggunakan rumus Frederer dan didapatkan hasil bahwa jumlah perlakuan (t) yang dipakai adalah 2, artinya pada kedua kelompok dilakukan sebanyak 16 kali percobaan.

Tujuan penelitian ini adalah untuk mengetahui perbandingan efektivitas daya hambat antibakteri ekstrak rimpang jahe merah (Zingiber officinale var rubrum) dengan formula obat kumur lidah buaya terhadap pertumbuhan bakteri Staphylococcus aureus.

Metode yang digunakan dalam penelitian ini adalah metode cakram disc diffusion menggunakan ekstrak rimpang jahe merah (Zingiber officinale var rubrum) dengan formula obat kumur lidah buaya. Penelitian dilakukan dengan menggunakan 32 cakram kosong yang direndam di dalam 4 wadah berbeda 
masing-masing berisi konsentrasi ekstrak rimpang jahe merah (Zingiber officinale var rubrum) 100\% dan formula obat kumur lidah buaya selama 15 menit. Sebanyak 1-2 ose dari biakan murni bakteri uji yang telah dikultur dan tumbuh disuspensikan dengan menggunakan $\mathrm{NaCl} 0,9 \%$ sampai diperoleh kekeruhan yang sama dengan standard Mc. Farland 0,5. Setelah itu disiapkan cawan petri berisi Mueller Hinton Agar (MHA) yang akan digunakan sebagai media uji bakteri. Staphylococcus aureus yang telah disuspensi diambil dengan menggunakan cottonbud steril dan digoreskan secara merata ke seluruh permukaan cawan petri yang berisi Mueller Hinton Agar (MHA).

Kemudian cakram kosong yang telah direndam bahan coba diletakkan disetiap area pada cawan petri. Setelah itu cawan petri diinkubasi di dalam inkubator pada suhu $37^{\circ} \mathrm{C}$ selama 24 jam. Setelah 24 jam, cawan-cawan petri tersebut dikeluarkan dari inkubator dan dilihat daya hambat yang terjadi pada setiap cakram dan diukur zona bening yang terbentuk dengan menggunakan kaliper.

\section{HASIL DAN PEMBAHASAN}

Setelah diamati pada masing-masing cakram yang telah direndam ekstrak rimpang jahe merah (Zingiber officinale var rubrum) dan formula obat kumur lidah buaya, diperoleh adanya zona hambat di sekitar cakram.

Tabel 1. Rata-rata diameter zona hambat kelompok perlakuan

\begin{tabular}{lccc}
\hline \multicolumn{1}{c}{ Kelompok perlakuan } & $\mathbf{n}$ & Mean $(\mathbf{m m})$ & $\begin{array}{c}\text { Standar } \\
\text { Deviasi }\end{array}$ \\
\hline $\begin{array}{l}\text { Ekstrak Rimpang Jahe Merah } \\
\begin{array}{l}\text { Formula Obat Kumur Lidah } \\
\text { Buaya }\end{array}\end{array}$ & 16 & 10,75 & 1,38 \\
\hline
\end{tabular}

Uji statistik yang digunakan pada penelitian ini menggunakan uji normalitas yaitu uji Shapiro-Wilk. Hasil menunjukkan data terdistribusi normal, maka dilanjutkan dengan uji Independent Sample T-test untuk melihat perbedaan pada kedua kelompok perlakuan. Uji Independent Sample T-test menunjukkan nilai $p=0,000 \quad(p<0,05)$ yang artinya bahwa ekstrak rimpang jahe merah $100 \%$ dan formula obat kumur lidah buaya memberikan efek antibakteri yang sangat signifikan dalam menghambat pertumbuhan bakteri Staphylococcus aureus.

Penelitian ini bertujuan untuk melihat perbandingan efektivitas daya hambat antibakteri antara ekstrak rimpang jahe merah (Zingiber officinale var rubrum) dengan formula obat kumur lidah buaya terhadap pertumbuhan bakteri Staphylococcus aureus. Efektivitas tersebut dilihat dari besarnya diameter zona bening yang terbentuk di sekeliling cakram yang sudah direndam dengan bahan uji yang diletakkan pada media Mueller Hinton Agar (MHA) yang diinokulasi bersama bakteri Staphylococcus aureus.

Metode yang digunakan adalah Metode Difusi Agar, yaitu dengan penempatan cakram yang mengandung bahan uji ke dalam mediaMueller Hinton Agar (MHA) yang telah digoreskan bakteri Staphylococcus aureus. Media Mueller Hinton Agar (MHA)tersebut diinkubasi pada suhu $37^{\circ} \mathrm{C}$ selama 24 jam dan dilakukan pengukuran zona bening di sekeliling cakram setelah 24 jam. ${ }^{15}$ 
Hasil penelitian menunjukkan adanya daya hambat yang dihasilkan oleh ekstrak rimpang jahe merah dan formula obat kumur lidah buaya terhadap pertumbuhan bakteri Staphylococcus aureus. Formula obat kumur lidah buaya memiliki daya hambat yang lebih efektif dibandingkan dengan ekstrak rimpang jahe merah yang dibuktikan dengan diameter zona bening disekitar cakram formula obat kumur lidah buaya lebih besar dibandingkan dengan ekstrak jahe merah. Pengulangan yang dilakukan sebanyak 16 kali memperlihatkan rata - rata zona hambat ekstrak jahe merah adalah 10,75 mm dengan diameter terbesar adalah 12,50 $\mathrm{mm}$ dan terkecil $9,00 \mathrm{~mm}$. Formula obat kumur lidah buaya memiliki rata-rata zona hambat adalah 12,82 $\mathrm{mm}$ dengan diameter terbesar adalah $14,70 \mathrm{~mm}$ dan terkecil adalah $10,50 \mathrm{~mm}$.

Zona hambat yang terbentuk disekeliling cakram memiliki ukuran diameter yang berbeda. Perbedaan ini bisa disebabkan karena beberapa faktor antara lain yaitu proses perendaman cakram didalam ekstrak rimpang jahe merah dan formula obat kumur lidah buaya tersebut terdapat perbedaan lamanya perendaman karena dalam pemindahan cakram ke cawan petri dilakukan satu persatu sehingga cakram yang pertama diletakkan dengan cakram yang terakhir diletakkan terdapat perbedaan waktu perendaman, goresan bakteri Staphylococcus aureus yang tidak merata, sehingga ada bagian dari media Mueller Hinton Agar (MHA) yang jumlah bakteri tumbuhnya tidak sama dengan bagian lainnya dan penggoresan bakteri yang sudah merata, namun tidak tumbuh sempurna, sehingga tidak terjadi efek antibakteri di sekeliling cakram tersebut.

Aktivitas antibakteri menurut Davis Stout dalam Rokhman (2007), dikelompokkan menjadi empat. Pertama, daya hambat tergolong lemah apabila diameter zona hambat antibakteri $<5 \mathrm{~mm}$. Kedua, daya hambat tergolong sedang apabila diameterzona hambat antibakteri 5-10 mm. Ketiga, daya hambat tergolong kuat apabila diameter zona hambat antibakteri 10-20 mm. Keempat, daya hambat antibakteri digolongkan sangat kuat apabila diameter zona hambat $>20 \mathrm{~mm} \cdot{ }^{16}$ Berdasarkan penjelasan tersebut, efek antibakteri pada ekstrak rimpang jahe merah dan formula obat kumur lidah buaya memiliki daya hambat yang kuat tetapi rata - rata diameter zona hambat pada formula obat kumur lidah buaya lebih besar dari ekstrak rimpang jahe merah.

Uji Independent Sample $T$-test pada penelitian ini menunjukkan nilai $\mathrm{p}=0,000$ yang berarti terdapat pengaruh yang sangat signifikan yang diberikan ekstrak rimpang jahe merah dan formula obat kumur lidah buaya terhadap pertumbuhan bakteri Staphylococcus aureus. Pengaruh yang signifikan ini dapat disebabkan karena kandungan antibakteri yang terdapat pada ekstrak rimpang jahe merah dan formula obat kumur lidah buaya.

Pembuatan ekstrak rimpang jahe merah dilakukan dengan metode maserasi yaitu merupakan ekstraksi simplisia segar menggunakan pelarut dengan cara perendaman, pengocokan, atau pengadukan pada temperatur ruangan. Mekanisme yang terjadi pada metode ini dengan cara masuknya pelarut kedalam dinding sel simplisia, sehingga senyawa yang terdapat pada dinding sel akan lepas dan masuk kedalam pelarut sehingga difusi senyawa yang terekstraksi oleh pelarut keluar dari dinding sel. Pelarut yang digunakan adalah etanol $96 \%$ karena tidak mempunyai efek antibakteri dan efektif untuk menarik senyawa aktif suatu simplisia. ${ }^{17}$

Ekstrak rimpang jahe merah dapat menghambat bakteri karena rimpang jahe merah memiliki zat aktif antibakteri seperti, gingerol, minyak atsiri, terpenoid, fenol, dan flavonoid. Senyawa gingerol memiliki 
efek antibakteri dengan cara merusak membran sitoplasma bakteri dan mendenaturasi protein. Minyak atsiri yang terkandung dalam rimpang jahe merah memiliki kandungan alkohol yang juga dapat mempengaruhi kerja antibakteri. Semakin banyak jumlah molekul alkohol maka makin meningkat kerja antimikroba pada rimpang jahe merah. ${ }^{18}$ Senyawa terpenoid yang terdapat pada rimpang jahe merah dapat mengakibatkan lisis pada sel bakteri dan dapat mengakibatkan kerusakan membran sel bakteri sehingga mengakibatkan terganggunya transport nutrisi pada sel bakteri. ${ }^{19}$ Senyawa fenol dan flavonoid memiliki efek antibakteri yang dapat menghambat sintesis dinding sel bakteri, mendenaturasi protein dan merusak membran sel bakteri. ${ }^{20}$

Pada penelitian Prasetya (2012) tentang efek antibakteri ekstrak jahe 20\%, 40\%, 60\% dan 80\% terhadap Streptococcus mutans dengan menggunakan metode difusi agar didapatkan hasil bahwa ekstrak dengan konsentrasi $80 \%$ merupakan konsentrasi efektif dalam menghambat bakteri Streptococcus mutans. Hal ini menunjukkan bahwa semakin besar konsentrasi maka semakin efektif suatu bahan antibakteri karena menghasilkan diameter zona hambat yang besar. ${ }^{8}$

Formula obat kumur lidah buaya juga memiliki zat antibakteri yang berasal dari beberapa senyawa kimia dan aloe barbadensis. Senyawa aloe barbadensis yang terdapat pada formula obat kumur lidah buaya mengandung senyawa saponin, tanin, antrakuinon, flavonoid, acemannan, dan asam fumarat.Saponin merupakan senyawa yang bersifat sebagai antiseptik yang mengakibatkan terjadinya kerusakan struktur lemak membran sel bakteri. Senyawa tanin dapat menghambat bakteri dengan cara bereaksi dengan sel membran, inaktivasi enzim- enzim esensial dan inaktivasi fungsi dari material genetik. ${ }^{17}$ Antrakuinon memiliki efek antibakteri dengan cara mengganggu integritas membral sel bakteri. Efek dari senyawa flavonoidterhadap bakteri dapat menghambat fungsi membran sitoplasma bakteri tersebut. Senyawa acemannan dan asam fumarat dapat menghambat bakteri dengan cara mengaktifkan makrofag dan mengganggu sintesis dinding sel bakteri. ${ }^{21}$

Hasil penelitian ini sesuai dengan penelitian yang dilakukan oleh Sari (2013) tentang uji antimikroba ekstrak segar jahe-jahean terhadap beberapa bakteri salah satunya Escherichia coli dengan metode difusi agar. Hasil penelitian tersebut menunjukkan ekstrak rimpang jahe merah memiliki efek antibakteri yang tergolong kuat dengan diameter zona hambat yang terbentuk dengan rata - rata 15,33 $\mathrm{mm}$, tetapi pada kedua penelitian ini didapatkan perbedaan rata-rata diameter zona hambat. ${ }^{15}$

Perbedaan diameter zona hambat yang terjadi dapat disebabkan karena ekstrak rimpang jahe merah yang dibuat pada penelitian sebelumnya dalam bentuk ekstrak kering, sedangkan pada penelitian ini ektrak rimpang jahe merah dibuat dalam bentuk ekstrak cair. Ada 2 faktor yang dapat mempengaruhi mutu ekstrak yaitu, faktor biologi seperti jenis tumbuhan, lokasi tumbuhan berasal, penyimpanan bahan tumbuhan, bagian yang digunakan dan umur tumbuhan, sedangkan faktor kimia seperti, jenis senyawa aktif yang terdapat pada tumbuhan, metode ekstraksi yang digunakan, pelarut yang digunakan, dan bentuk hasil ekstraksi yang diperoleh. ${ }^{22}$

Ekstrak cair merupakan ekstrak berbentuk cair yang diperoleh dari hasil penyarian dengan atau tanpa proses penguapan penyari dan masih ada terdapat sedikit pelarut atau air di dalamnya, sedangkan ekstrak kering adalah ekstrakberbentuk kering yang diperoleh dari proses penguapan penyari dengan atau 
tanpa bahan tambahan tetapi proses pengeringan yang dilakukan lama dan dapat merusak zat aktif yang ada pada bahan. ${ }^{22}$

Pada penelitian ini ada beberapa faktor kelemahan yang dapat mempengaruhi dalam proses penelitian seperti, perbedaan lamanya perendaman cakram dalam waktu pemindahan cakram ke cawan petri yang dilakukan satu persatu sehingga cakram yang pertama diletakkan dengan cakram yang terakhir diletakkan terdapat perbedaan waktu perendaman yang dapat mempengaruhidiameter yang terbentuk disekitar cakram dan ekstrak rimpang jahe merah yang dihasilkan dalam bentuk cair yang masih terkandung air atau pelarut sekitar $10 \%$ yang dapat mempengaruhi zat aktif yang terkandung didalam ekstrak dan mempengaruhi diameter yang terbentuk disekitar cakram.

\section{SIMPULAN}

Ekstrak rimpang jahe merah (Zingiber officinale var rubrum) dengan konsentrasi $100 \%$ dan formula obat kumur lidah buaya memiliki efek antibakteri yang dapat menghambat pertumbuhan bakteri Staphylococcus aureus yang menunjukkan rata-rata diameter zona hambat 10,75 mm dan 12,82 mm dengan kategori kuat. Formula obat kumur lidah buaya lebih efektif dibandingkan dengan ekstrak rimpang jahe merah (Zingiber officinale var rubrum) dengan konsentrasi $100 \%$ dalam menghambat pertumbuhan bakteri Staphylococcus aureus.

\section{KEPUSTAKAAN}

1. Ganitafuri, H. Daya Hambat Ekstrak Daun Lidah Buaya (Aloe vera L.) Terhadap Pertumbuhan Isolat Klinis Bakteri Streptococcus $\beta$ hemolyticus in Vitro. [Skripsi]. 2010. Universitas Sebelas Maret, Surakarta.

2. Tim Bina Karya Tani. Budidaya Tanaman Jahe. 2009. Yrama Widya. Bandung.

3. Zakiah, Syarifah. Uji Daya Hambat Antibakteri Ekstrak Rimpang Jahe Merah Bakteri Terhadap Gram Positif dan Gram Negatif. [Skripsi] 2010. Fakultas Farmasi Universitas Pancasila.

4. Fissy, Syf. Octy Novy. Uji Efektivitas Sediaan Gel Anti Jerawat Ekstrak Etanol Rimpang Jahe Merah (Zingiber officinale var. rubrum) Terhadap Propionibacterium acnes dan Staphylococcus epidermis. 2013. Fakultas Kedokteran Universitas Tanjungpura.

5. Rohula Utami, Kawiji, Edhi Nurhartadi, Muslika Kurniasih, dan Dedy Indianto (2013). Pengaruh Minyak Atsiri Jahe Merah dan Lengkuas Merah Pada Edible Coating Terhadap Kualitas Fillet lkan Patin. Agritech, Vol. 33, No. 4, November 2013: 399 - 406.

6. Erikawati, Daniati Tri. Perbandingan Desinfektan Sodium Hipoklorit 0,5\% dan Ekstrak Jahe Merah 100\% Sebagai Bahan Pembersih Gigi Tiruan Terhadap Perubahan Warna Pada Resin Akrilik Heat Cured. 2012. Fakultas Kedokteran Gigi Universitas Jember.

7. Nurina, Saskia Budi. Konsentrasi Efektif Ekstrak Jahe Merah Sebagai Pembersih Gigi Tiruan Resin Akrilik Terhadap Jumlah Streptococcus mutan. 2010. Fakultas Kedokteran Gigi Universitas Jember.

8. Prasetya, Bagi. Efektifitas Daya Antibakteri Ekstrak Jahe Terhadap Pertumbuhan Streptococcus mutans (In Vitro). 2012. Fakultas Kedokteran dan Ilmu Kesehatan universitas Yogyakarta. 
Fakultas Kedokteran Gigi Universitas Andalas

Jalan Perintis Kemerdekaan No. 77 Padang, Sumatera Barat

Web: adj.fkg.unand.ac.id Email: adj@dent.unand.ac.id

9. Hayati, K. Efek Anti Bakteri Ekstrak Lidah Buaya (Aloe vera) Terhadap Staphylococcus aureus Yang Diisolasi Dari Denture Stomatitis (Penelitian In Vitro). [Skripsi]. 2019. Universitas Sumatera Utara, Medan.

10. Sulistiawati, I Dewa Ayu Nuraini. Pemberian Ekstrak Daun Lidah Buaya (Aloe Vera) Konsentrasi $75 \%$ Lebih Menurunkan Jumlah Makrofag Dari Pada Konsentrasi 50\% dan 25\% Pada Rahang Mukosa Mulut Tikus Putih Jantan. [Thesis]. 2011. Universitas Udayana, Denpasar.

11. Celik c, Yuzugulla B, Erkut S, Yamanel K. Effect of mouthrinses on color stability of resin composite. Eur J Dent.2008.

12. Soeherwin, Mangundjaja, Rini Khairun Nisa. Pengaruh Obat Kumur Klorheksidin Terhadap Populasi Kuman Streptococcus Mutans Di Dalam Air Liur.2000. Universitas Indonesia.

13. Kusuma, Sri Agung F. Staphylococcus aureus. 2009. Fakultas Farmasi Universitas Padjadjaran.

14. Shweta, S Krishna Prakash. Dental Abscess: A Microbiological Review. Dental Research Journal 2013; Sept - Oct, 10(5): 585 - 591.

15. Sari, Kartika Indah Permata, Periadnadi dan Nasril Nasir. Uji Antimikroba Ekstrak Segar Jahe-Jahean (Zingiberaceae) Terhadap Staphylococcus aureus, Escherichia coli dan Candida albicans. Jurnal Biologi Universitas Andalas 2013; Vol. 20-24 (ISSN: 2303-2162).

16. Rokhman, Fatkur. Aktivitas Antibakteri Filtrat Bunga Teleng (Clitoria ternatea I) Terhadap Bakteri Penyebab Konjungtivitis. 2007. Institusi Pertanian Bogor.

17. Winarsih, Sri. Uji Efek Ekstrak Etanol Lidah Buaya Sebagai Antimikroba Terhadap Bakteri Escherchia coli Secara In Vitro. Jurnal Penelitian.2010.

18. Kusumawardani, Irene Retno, Kusdarwati Rahayu, dan Didik Handijatno. Daya Antibakteri Ekstrak Jahe Merah (Zingiber officinale Rosc.) Dengan Konsentrasi yang Berbeda Terhadap Perumbuhan Aeromonas hydrophila Secara In Vitro. Jurnal Berkala Penelitian Perikanan, 2008; Vol 3 Hal 75 - 82.

19. Purwani, Eni, Setyo Wulang N. H., dan Rusdin Rauf. Respon Hambat Bakteri Gram Positif dan Negatif Pada Ikan Nila (Oreochromis niloticus) yang Diawetkan Dengan Ekstrak Jahe (Zingiber officinale). Jurnal Kesehatan ISSN 1979-7621, 2009; Vol. 2: 61-70.

20. Ajizah, A., Thihana dan Mirhanuddin (2007). Potensi Ekstrak Kayu Ulin (Eusideroxylon zwageri $T$ et B) Dalam Menghambat Pertumbuhan Bakteri Staphylococcus aureus Secara in Vitro. Jurnal IImiah. 4(1): 37-42.

21. Idris, M. Efektifitas Aloe Vera Terhadap Pertumbuhan Streptococcus Sanguis. [Skripsi]. 2013. Universitas Hasanudin, Makassar.

22. Badan POM RI. Pedoman Teknologi Formulasi Sediaan Berbasis Ekstrak Volume 2. Direktorat Obat Asli Indonesia 2013; h: 4 - 11. 